\title{
Pertimbangan Anestesi Perioperatif untuk Pasien Bedah Saraf dengan Covid-19
}

\author{
Dewi Yulianti Bisri*), Tatang Bisri $\left.{ }^{* *}\right)$ \\ *) Departemen Anestesiologi dan Terapi Intensif Fakultas Kedokteran Universitas Padjadjaran-Bandung \\ **) Departemen Anestesiologi dan Terapi Intensif Fakultas Kedokteran Universitas Jenderal Achmad Yani-Cimahi \\ Bandung
}

\begin{abstract}
Abstrak
Coronavirus yang baru, severe acute respiratory syndrome coronavirus 2 (SARS-CoV-2) pertamakali timbul di Wuhan, Provinsi Hubei Cina, pada bulan Desember 2019, dan menyebar dengan cepat ke seluruh dunia ke lebih dari 190 negara. Pasien harus ditapis untuk covid-19 menggunakan kombinasi riwayat penyakit, computed tomography (CT) dada, dan pemeriksaan real time quantitative polymerase chain reaction (RT-qPCR) bergantung kebijakan institusinya. Keluhan neurologis seperti dizziness, headache, hypogeusia dan hyposmia, sering (36\%) pada pasien covid-19. Encefalopati dan perubahan status mental juga terjadi pada pasien yang telah terinfeksi dengan virus SARS-CoV-2. Penyakit serebrovaskuler lebih sering pada covid-19 yang berat; acute ischemic stroke telah dilaporkan pada $5,7 \%$ dan gangguan kesadaran pada $15 \%$ pasien. Tindakan pembedahan rutin kranial dan spinal aman untuk dilakukan. Operasi endoscopic endonasal tidak aman dan harus dihindari. Ekstubasi setelah anestesi umum bila memungkinkan dilakukan di ruangan tekanan negatif, personil tetap memakai alat pelindung diri (APD) level 3. Harus dihindari pasien batuk saat ekstubasi. Setelah ekstubasi, pasang oksigen binasal, dan pasien harus memakai masker bedah dan aliran oksigen tinggi harus dihindari (berikan $<6 \mathrm{~L} /$ menit) untuk menghindari terjadinya aerosolisasi
\end{abstract}

Kata kunci: Covid-19, neurologik, manifestasi, anestesia, perioperatif

JNI 2021; 10 (1): 55-62

\section{Perioperative Anesthesia Consideration for Neurosurgical patients with Covid-19}

\begin{abstract}
The novel coronavirus, severe acute respiratory syndrome coronavirus 2 (SARS-CoV-2) emerged in Wuhan, Hubei province China, in December 2019, and spread fast to all the world more than 190 countries. Patients should be screened for covid-19 using a combination of history, computed tomography (CT) chest, and real time quantitative polymerase chain reaction (RT-qPCR) testing depending on institutional policies. Neurological symptom as dizziness, headache, hypogeusia and hyposmia, common (36\%) at covid-19 patient. Encephalopaty and changed mental status exist in patient infected by SARS-CoV-2 virus. Cerebrovascular diseases more in severe covid-19; acute ischemic stroke had reported in $5.7 \%$ and altered level of consciousnes in $15 \%$ patient. Surgical measuremet cranial and spinal rutine is safe, endoscopic endonasal surgery not safe and must be avoided. Extubation after general anesthesia if possible do air negative pressure room, and personil still use personal protection equipment (PPE) level 3. Must be avoid patient cough during extubation. After extubation, give oxygen nasal canule, surgical mask, and high flow oxygen (give $<6 \mathrm{~L} / \mathrm{min}$ ) avoided given the risk of aerosolization
\end{abstract}

Key words: Covid-19, neurological, manifestation, anesthesia, perioperative

JNI 2021; 10 (1): 55-62 


\section{Pendahuluan}

Coronavirus yang baru, severe acute respiratory syndrome coronavirus 2 (SARS-CoV-2) pertamakali timbul di Wuhan, Provinsi Hubei Cina, pada bulan Desember 2019, dan menyebar dengan cepat ke seluruh dunia ke lebih dari 190 negara. ${ }^{1,2}$ Tanggal 18 Desember hingga 29 Desember 2019, terdapat lima pasien yang dirawat dengan acute respiratory distress syndrome (ARDS). Sejak 31 Desember 2019 hingga 3 Januari 2020 kasus ini meningkat pesat, ditandai dengan dilaporkannya sebanyak 44 kasus. Tidak sampai satu bulan, penyakit ini telah menyebar di berbagai provinsi lain di Cina. Awalnya, penyakit ini sementara dinamakan sebagai 2019 novel coronavirus (2019-nCoV). World Health Organization (WHO) pada tanggal 11 Pebruari 2020, telah menamakan penyakit yang disebabkan virus ini sebagai corona virus disease (covid) dan karena mulai terjadi tahun 2019 maka dinamai covid-19. Penyakit ini disebabkan oleh virus severe acute respiratory syndrome coronavirus-2 (SARS-CoV-2) dan pada 11 Maret 2020 dinyatakan sebagai pandemik. ${ }^{2-4}$ Covid-19 khas dengan adanya demam (89\%), batuk (58\%), dyspnoe (46\%), mialgia (29\%), limpopenia dan gambaran opasitas dan konsolidasi ground glass bilateral. ${ }^{5,6}$

Walaupun rentang keluhan dapat dari ringan sampai berat, gejala klinis utama yang muncul yaitu demam (suhu $>38^{\circ} \mathrm{C}$ ), batuk dan kesulitan nafas. Selain itu dapat disertai dengan sesak memberat, fatigue, mialgia, gejala gastrointestinal seperti diare dan gangguan saluran nafas lainnya, 20\% pasien yang terinfeksi memerlukan perawatan di intensive care unit (ICU). ${ }^{5}$ Spektrum klinis penyakitnya sangat lebar, dari mulai ringan tanpa keluhan spesifik, seperti demam, batuk kering dan diare, kadang-kadang kombinasi dengan pneumonia ringan dan sesak ringan ke pneumonia berat dengan dispnoe, tachipnoe dan gangguan pertukaran gas, membawa $5 \%$ pasien yang terinfeksi kearah disfungsi paru berat, kebutuhan untuk ventilasi, syok atau gagal organ multipel. ${ }^{4,5}$ Ada hubungan erat antara thrombosis dan inflamasi, dua proses yang saling menguatkan satu sama lain.
Faktorrisiko untuk terjadilevel beratataukematian akibat covid-19 adalah usia tua, perokok, chronic obstructive pulmonary disease (COPD), diabetes, hipertensi, immunocompromise dan malignansi. ${ }^{7,8}$ Penyakit ini mempunyai beberapa implikasi yang berhubungan dengan neuroanesthesiologist antara lain manifestasi neurologik dan implikasi untuk prosedur bedah saraf khusus seperti bedah saraf emergensi, intervensional neuroradiologi, bedah saraf transnasal, awake craniotomy, terapi elektrokonvulsif, serta keselamatan tenaga medisnya sendiri. ${ }^{4}$ Akan tetapi, disebabkan karena kelemahan hasil false negatif disebabkan oleh rendahnya viral load pada sampel dan kit pendeteksi yang relatif tidak cukup, banyak pasien yang tidak dapat dideteksi saat ini. Walaupun keluhan klinis, riwayat epidemiologis dan manifestasi CT-scan telah ditambahkan pada kriteria diagnostik penyakit ini, adanya gejala klinis yang tidak khas, tidak jelas riwayat epidemiologik, kesimpulan imaging yang ambigu menyebabkan kesulitan dalam melakukan skrining pasien. ${ }^{4}$ Tindakan neuroanestesi pada pasien dengan covid-19 memerlukan beberapa pertimbangan khusus selain mencegah terjadinya transmisi virus ke petugas kesehatan dan alatalat kamar operasi. Penggunaan alat pelindung diri (APD) level 3 harus dipertimbangkan karena kemungkinan kontak dengan airway pasien saat induksi laringoskopi intubasi. Akan tetapi, prinsip kami adalah setiap pasien yang akan dilakukan pembiusan, maka dianggap covid-19 positif dan spesialis anestesi yang bekerja diwajibkan memakai APD level 3.

\section{Diagnosa Covid-19}

Diagnosa covid-19 diambil dari riwayat penyakit, pemeriksaan fisik dan pemeriksaan penunjang. Manifestasi klinis pasien covid-19 memiliki spektrum yang luas, mulai dari tanpa gejala (asimtomatik), gejala ringan, pneumonia, pneumonia berat, acute respiratory distress syndrome (ARDS), sepsis, hingga syok sepsis. Sekitar $80 \%$ kasus tergolong ringan atau sedang, $13,8 \%$ mengalami sakit berat, dan sebanyak $6,1 \%$ pasien jatuh ke dalam keadaan kritis. Berapa besar proporsi infeksi asimtomatik belum diketahui. Viremia dan viral load yang tinggi dari 
swab nasofaring pada pasien yang asimptomatik telah dilaporkan. ${ }^{2}$

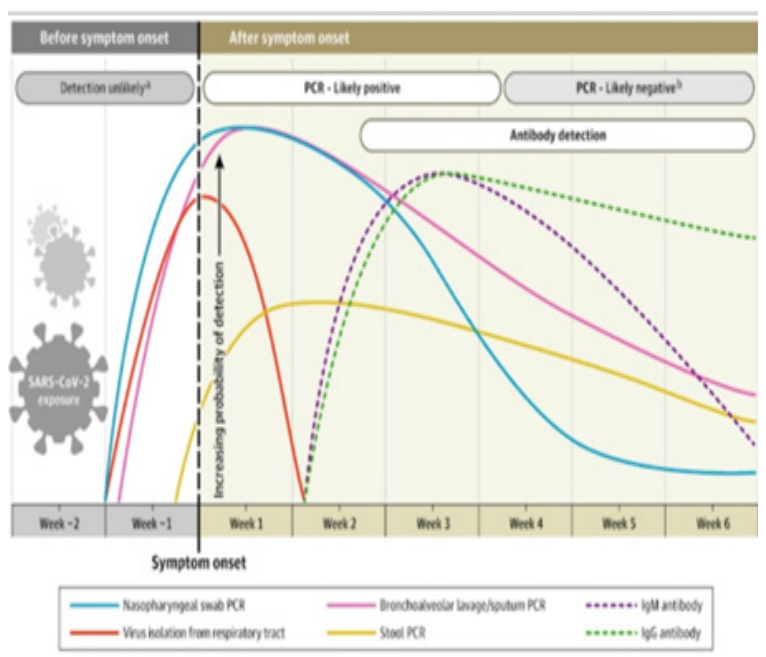

Gambar 1. Untuk Mendeteksi Infeksi Virus SARS-COV-2

Dikutip dari ctkbiotech.com. ${ }^{9}$

Kriteria yang diterima untuk diagnosis covid-19 adalah salah satu dari:

1) Real time quantitative polymerase chain reaction (RT-qPCR) positif untuk asam nukleat covid-19; 2) genetik virus diidentifikasi dengan gene sequencing adalah highly homologous dengan covid-19; atau, 3) adanya antibodi IgM dan IgG covid-19 yang spesifik. ${ }^{2,4}$ Gambar 1 memperlihatkan kapan bisa mendeteksi dengan pemeriksaan swab antigen, swab PCR dan serum antibodi.

\section{Manifestasi Neurologik dari Covid-19}

Manifestasi neurologik dari covid-19 baru-baru ini telah disampaikan. Bukti awal yang tidak dipublikasikan menunjukkan bahwa pada pasien dengan covid-19 positip terjadi peningkatan risiko stroke iskemik akut. Satu laporan dari Cina menunjukkan bahwa keluhan neurologis seperti dizziness, headache, hypogeusia dan hyposmia, sering terjadi (sekitar 36\%) pada pasien covid-19. ${ }^{4,10-15}$ Ensefalopati dan perubahan status mental juga terjadi pada pasien yang telah terinfeksi dengan virus SARS-CoV-2. Penyakit serebrovaskuler lebih sering pada covid-19 yang berat; stroke iskemik akut telah dilaporkan terjadi pada 5,7\% pasien dan gangguan kesadaran pada 15\% pasien., ${ }^{40-15}$ Hasil ini konsisten dengan laporan lain yang dilakukan di Wuhan Cina pada 221 pasien dimana ditemukan kejadian 5\% stroke iskemik akut dan 1\% kejadian perdarahan serebral. Pada penelitian cohort ini, pasien dengan komplikasi serebrovaskular lebih sering pada usia yang lebih tua, mengalami penyakit covid-19 berat, menunjukkan bukti adanya hiperkoagulabilitas dan inflamasi. Akhirnya, $38 \%$ pasien dengan komplikasi serebrovaskuler meninggal. Bersama-sama, laporan-laporan pendahuluan ini menunjukkan bahwa pasien dengan covid-19 lebih sering mendapatkan terapi endovaskular dari stroke iskemik akut dan juga peningkatan risiko stroke perioperatif bila mereka memerlukan pembedahan selama infeksi akut. ${ }^{4,10-15}$ Coronavirus lain yang hampir sama dengan SARS-CoV-2 telah menunjukkan menyerang susunan saraf pusat. Virus SARS$\mathrm{CoV}$ dan middle east respiratory syndrome coronavirus (MERSCoV) sangat mirip dengan virus SARS-CoV-2 dalam struktur dan jalur infeksi dan keduanya menunjukkan menginfeksi susunan saraf pusat (SSP) pada hewan model; batang otak ditemukan terinfeksi berat oleh

\section{Tabel 1. Manifestasi Neurological Covid-19}

Keluhan neurologik yang sering terjadi adalah: sakit kepala, pusing,

perubahan pengecapan dan penciuman

Lima persen risiko terjadinya stroke iskemik akut.

Coronavirus mempunyai kecenderungan untuk menginvasi SSP.

Dikutip dari: Flexman AM, dkk ${ }^{4}$

SARS-CoV dan MERS-CoV. Selanjutnya, infeksi SSP ini berhubungan dengan tingginya laju mortalitas yang kemungkinan karena disfungsi pusat kardiorespirasi di batang otak. .,10-15 $^{4}$ Perubahan penciuman yang telah dilihat pada covid-19, diposulatkan karena refleks akses dari virus ke otak melalui rute transcribial, walaupun masih perlu dibuktikan untuk SARS$\mathrm{CoV}-2$. Secara keseluruhan, invasi langsung ke SSP adalah masuk akal, dan merupakan alasan keluhan neurologis yang dilaporkan pada pasien dengan covid-19 positif. ${ }^{4,10-15}$ 


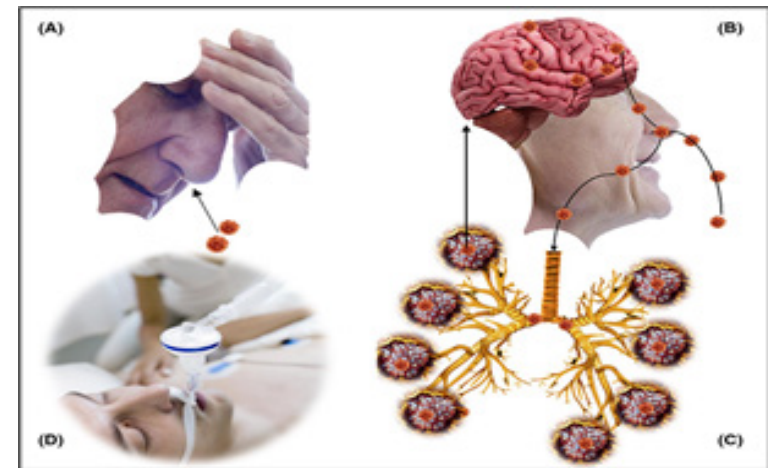

Gambar 2. Manifestasi neurologik covid-19. Demam dan sakit kepala (A) bisa terjadi awal pada pasien covid-19. Manifestasi spesifik yang berhubungan dengan defisit neurologik seperti hilangnya penciuman, pengecapan, ataksia, kejang. Kemungkinan tempat masuknya SARS-CoV-2 ke otak melalui cribriform plate (B) atau setelah infeksi paru (C), pada fase awal atau late phases covid-19 mungkin mengakibatkan hilangnya kontrol pernafasan yang memerlukan bantuan ventilasi (D)

Dikutip dari: Baig MA ${ }^{10}$

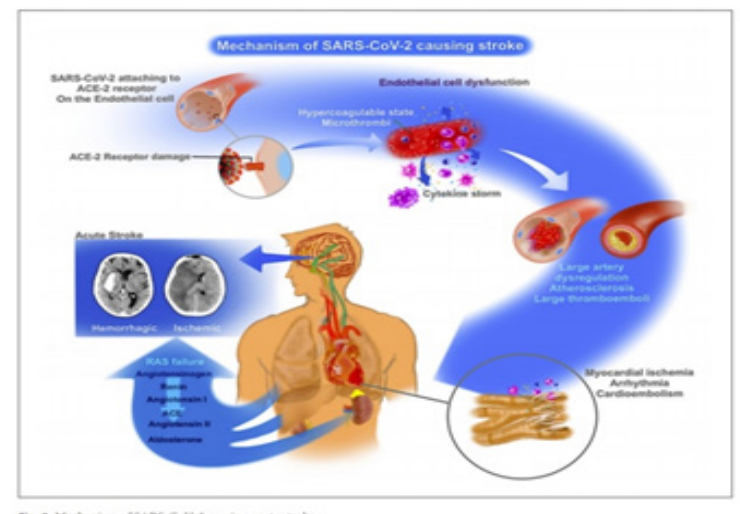

Gambar 3. Mekanisme covid-19 menyebabkan stroke

Dikutip dari: Kolikonda MK, et al. ${ }^{11}$

\section{Transmisi Covid-19 selama Prosedur Bedah Saraf}

Saat setiap negara membatasi pembedahan kearah pembedahan emergensi, tapi tetap ada pasien yang membutuhkan pembedahan, menjadi penting mengenal transmisi covid-19 selama pembedahan saraf terutama saat drill atau endoscopy. Seperti halnya kebanyakan saran pada keadaan krisis, banyak panduan nasional atau internasional,

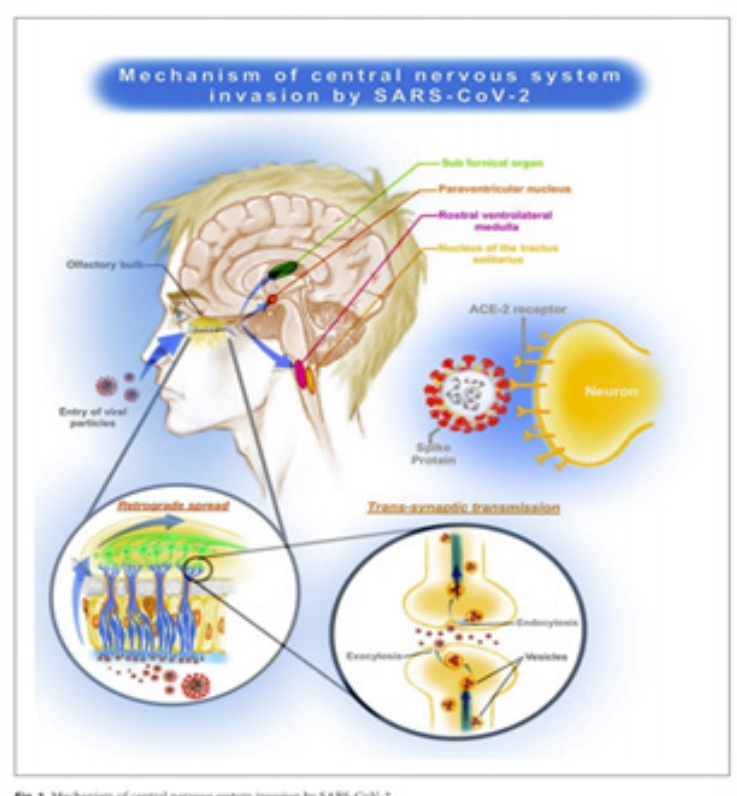

Gambar 4. Mekanisme Invasi SARS-CoV-2 ke SSP Dikutip dari: Kolikonda MK, et al. ${ }^{11}$

bukti-bukti yang dipublikasikan, pendapat pakar, dsbnya. Sebagai contoh di Inggris menganjurkan penggunaan personal protection equipment/ PPE (APD; alat pelindung diri) untuk semua prosedur. ${ }^{16,17}$ Akan tetapi, secara prinsip covid-19 terutama menyebar secara langsung atau melalui fomites (benda atau permukaan yang dapat terkontaminasi dengan patogen dan berfungsi sebagai kendaraan dalam menularkan penyakit dari satu orang ke orang lain), melalui droplet dari epitel respirasi terutama saluran nafas bagian atas. Darah bukan merupakan alat pembawa, bila virus berada dalam darah, lebih mudah bagi kita untuk mendeteksinya. Hal yang sama juga tidak terlihat pada cairan serebrospinal. Kebanyakan kasus covid-19 mempunyai bukti transmisi dari manusia ke manusia. Virus ini dapat disolasi dari droplet atau sekresi respiratori, faeces dan fomites. Transmisi virus terjadi lebih sering melalui kontak dengan orang yang terinfeksi (dalam 2 meter) atau dari permukaan yang terkontaminasi. ${ }^{4,13,14,16,17}$

Jadi kebanyakan prosedur bedah saraf pada spine dan kepala, aman bila kita menggunakan pelindung muka dan mata bila APD tidak tersedia. Ini termasuk drilling (pengeboran) kranial dan spinal. Kehati-hatian dibutuhkan pada prosedur 
anterior skull base yang mungkin menembus sinus udara. Sebaliknya prosedur endonasal sangat berisiko. Penggunaan debriders dan drills dalam cavum nasi akan menghasilkan droplet aerosol yang sangat berbahaya. Di Wuhan, ahli bedah telinga hidung tenggorokan (THT) diantara yang paling buruk terkena dan masker N95 tidak bisa mencegah infeksi. ${ }^{4}$ Kebanyakan pasien pituitari menunjukkan keadaan subakut, dan diharapkan bersedia menunggu, akan tetapi, kita akan bersalah bila pasien sampai buta dalam proses menunggu ini. Bila operasi tidak bisa ditunda, berikan pertimbangan sebagai alternatif dari pembedahan endoskopi dengan: ${ }^{4,15}$ kraniotomi, operasi trans-sphenoidal microscope based, dengan pendekatan submukosal dan masuk ke sella menggunakan teknik non-drill, APD harus dipakai oleh seluruh staf kamar operasi dan hati-hati dengan sekresi nasal, pemeriksaan preoperatif covid-19 harus dilakukan. Sebagai kesimpulan: Tindakan pembedahan rutin kranial dan spinal aman untuk dilakukan. Operasi endoscopic endonasal tidak aman dan harus dihindari. ${ }^{4}, 15$

\section{Prosedur Bedah Saraf Emergensi}

Anesthesiologists harus menggunakan rekomendasi yang telah dipublikasikan untuk pengelolaan perioperatif pasien covid-19, yang dapat disimpulkan sebagai berikut ${ }^{4}, 17$ : 1) untuk menghemat APD dan membatasi eksposure, hanya personil penting yang boleh hadir saat

Table 2. Prosedur Bedah Saraf Emergensi selama Pandemic Covid-19

Akan ada bedah saraf yang urgen selama pandemik covid-19 dan dapat disentralisasi untuk membatasi sumber daya

Pasien harus di skrining untuk covid-19 dengan: riwayat penyakit, CT toraks, dan pemeriksaan RTqPCR bergantung pada aturan RS

Pasien yang dilakukan prosedur bedah saraf emergensi harus dianggap menderita covid-19 sampai informasi lain tersedia

Anestesi umum untuk pasien suspek atau terkonfirmasi covid-19 harus dikerjakan menggunakan APD

Dikutip dari: Flexman AM, dkk ${ }^{4}$ tindakan yang menyebabkan terbentuknya aerosol yang terjadi selama anestesi umum; 2) Idealnya, induksi anestesi dan intubasi harus dilakukan oleh yang berpengalaman dalam ruangan tekanan negatif, dan intubasi menggunakan rapid sequence induction dengan video laryngoscopy sambil meminimalkan bagmask ventilasi; 3) Ekstubasi setelah anestesi umum, bila memungkinkan, juga dilakukan pada ruangan tekanan negatif menggunakan airborne PPE; 4) Batuk harus dicegah selama ekstubasi; 5) Pasien harus memakai masker bedah setelah ekstubasi and hindari pemberian high flow oxygen (misalnya berikan $\mathrm{O}_{2}<6 \quad \mathrm{~L} /$ menit) karena adanya risiko aerosolisasi; 6) Pasien yang telah diekstubasi harus diberikan oksigen memalui sungkup muka dan bila mungkin dipasang masker bedah dibawahnya; 7) Terakhir, transportasi pasien juga memerlukan perhatian untuk keamanan dan meminimalkan kontaminasi.

\section{Table 3. Prosedur Bedah Saraf Transnasal}

Memberikan tingkatan tinggi untuk sebaran virus dari mukosa nasopharingeal, prosedur transnasal menghasilkan aerosolisasi virus ke lingkungan.

Baru-baru ini, organisasi bedah saraf and otolaringologi telah merekomendasikan skrining pasien untuk keluhan covid-19, pemeriksaan preoperatif dan pertimbangan alternatif bedah lain untuk operasi transnasal

Dikutip dari: Flexman AM, dkk $^{4}$

\section{Prosedur Bedah Saraf Transnasal}

Virus SARS-CoV-2 dipercaya banyak terdapat di mukosa nasal, dan laporan dari Wuhan, Cina, menggaris bawahi operasi nasal, seperti transsphenoidal hypophysectomy, terhadap kemungkinan aerosolisasi virus yang tinggi untuk terjadinya transmisi virus. Saatawal daripandemik di Cina, sebelum dilakukan pemeriksaan yang luas, emergensi transsphenoidal hypophesectomy menyebabkan viral transmission kepada tenaga kesehatan dalam beberapa hari setelah operasi, walaupun dengan menggunakan APD yang tepat. ${ }^{4,18}$

\section{Anestesi Umum}

Idealnya, induksi anestesi dan intubasi dilakukan 
Table 4. Awake Craniotomy

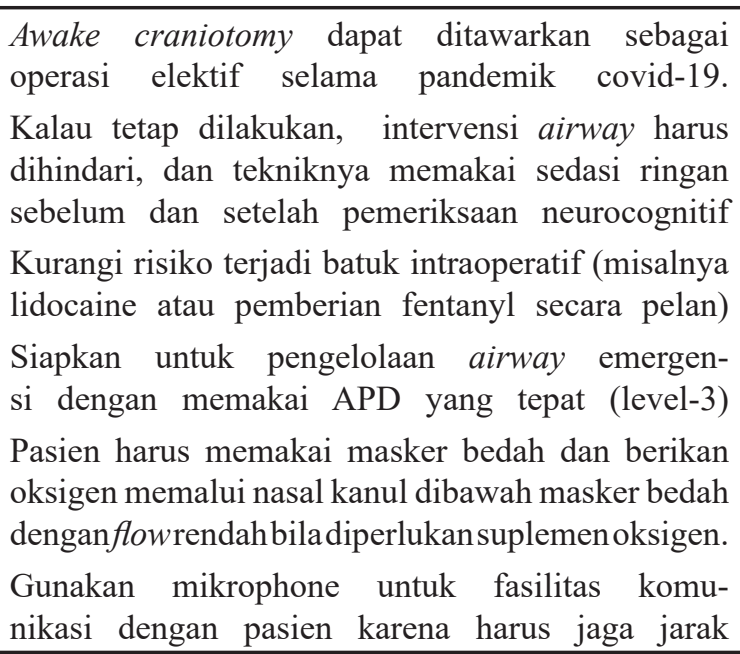

oleh tenaga ahli yang berpengalaman dalam ruangan bertekanan negatif. Intubasi dilakukan dengan teknik videolaringoscopi seraya mengurangidilakukanventilasidengan bag-mask. ${ }^{4}$

\section{Awake Craniotomy}

Perbedaan teknik anestesi untuk awake craniotomy telah diuraikan yaitu awake tanpa sedasi, conscious sedation atau monitored anesthesia care, asleep-awake technique, dan asleep-awake-asleep technique. Teknik yang dipilih harus familier, sambil mengurangi risiko harus dilakukan intervensi jalan nafas. Terserah teknik apa yang dipilih, selama pandemi covid-19 batuk selama awake craniotomy harus dicegah untuk mengurangi kemungkinan kontaminasi dan aerosolisasi. ${ }^{4}$

\section{Table 5. Prosedur Neurointerventional Radiology}

Pasien yang suspek Covid-19 harus diperiksa sebelum dilakukan tindakan.

Intubasi dan ekstubasi idealnya dilakukan di ruang isolasi, yang bisa berada diluar ruangan radiologik intervensional

Baju timbal harus dipakai dibawah APD karena spesialis anestesi mungkin harus berada di ruang radiologik tersebut

Dikutip dari: SNACC ${ }^{4}$

\section{Prosedur Neurointerventional Radiology}

Dengan pengecualian terapi endovaskular untuk stroke iskemik akut, kebanyakan prosedur radiologik intervensional yang dilakukan selama pandemik dipertimbangkan urgent, daripada emergent (misalnya embolisai aneurisma intrakranial, tumorspine). Karena itu, setiap pasien dengan suspek covid-19 harus diperiksa sebelum dilakukan tindakan (tersedia pemeriksaan cepat $<24$ jam), dan selama tindakan memakai APD. ${ }^{4}$

\section{Electroconvulsive Therapy (ECT)}

Terapi electroconvulsive adalah suatu terapi yang efektip untuk kelainan neurologik dan psikiatrik. Selama pandemi covid-19, ada peningkatan kebutuhan dilakukannya ECT. Pandemik kelihatannya menyebabkan kerusakan kesehatan mental. ${ }^{4}$

\section{Table 6. Terapi Electroconvulsif (ECT)}

ECT dipertimbangan sebagai tindakan lifesaving pada beberapa kasus dan tidak bisa ditunda, walaupun opsi terapi lain harus ditunda

Kelompok yang dilakukan ECT berisiko tinggi terpapar dan mengalami morbiditas covid-19.

Pasien harus covid-19 negatif dan tanpa keluhan bila akan dilakukan ECT

Ventilasi dengan bag mask meningkatkan risiko aerosolisasi dan kontaminasi, maka harus dihindari.

Dikutip dari: Dikutip dari: Flexman AM, dkk ${ }^{4}$

\section{Keselamatan Tenaga Kesehatan}

Selama pandemik, konsep "duty to treat" (kewajiban untuk merawat) oleh tenaga kesehatan tetap dilakukan walaupun mengalami banyak perubahan dalam melaksanakannya dan adanya risiko bagi tenaga kesehatan. Gagasan pengorbanan diri adalah kesalahan fatal. ${ }^{5}$ Selama pandemik, kesehatan mental dan fisik tenaga kesehatan harus dijaga, prosedur yang lama, kelelahan fisik, tingginya risiko kontaminasi, stres psikologis sering terjadi pada praktek neuroanestesi, departemen Neuroanesthesiologi harus menjamin penambahan staf supaya dapat istirahat dan bantuan klinis selama tindakan yang lama, terutama bila diharuskan memakai APD, perhimpunan spesialis memberikan strategi untuk menghilangkan stres dan memperbaiki kesehatan. ${ }^{4}$ 


\section{Ekstubasi}

Ekstubasi setelah anestesi umum bila memungkinkan dilakukan di ruangan tekanan negatif, personil tetap memakai APD level 3 . Harus dihindari terjadinya pasien batuk saat ekstubasi. Setelah ekstubasi, pasang oksigen binasal, dan pasien harus memakai masker bedah dan pemberian oksigen dengan flow tinggi harus dihindari untuk mencegah terjadinya aerosolisasi, berikan flow oksigen $<6 \mathrm{~L} / \mathrm{min})^{4,19,20}$

\section{Simpulan}

Sejak virus SARS-CoV-2 pertamakali ditemukan di akhir 2019 di Cina, pandemik covid-19 menyebar ke seluruh dunia dan menyebabkan kerusakan masif dalam masalah kesehatan. Neuroanesthesiologists harus waspada pada beberapa pertimbangan khusus yang berhubungan dengan anestesi untuk bedah saraf dan neurointervensional emergensi seperti ECT. Tindakan pembedahan rutin kranial dan spinal aman untuk dilakukan. Operasi endoscopic endonasal tidak aman dan harus dihindari. Rekomendasi-rekomendasi ini akan terus berkembang sesuai perkembangan pandemik, terutama sesuai yang kita ketahui tentang pengertian patofisiologi, tindakan klinik, dan opsi terapi covid-19.

\section{Daftar Pustaka}

1. Huang C, Wang Y, Li X, Ren L, Zhao J, Hu Y, et al. Clinical features of patient infeted with 2019 novel coronavirus in Wuhan, China. Lancet 2020;395: 497-506.

2. Burhan E, Susanto AD, Nasution SA, Ginanjar E, Pitoyo CW, Susilo A, dkk. Pedoman tatalaksana Covid-19 Edisi 2, Agustus 2020

3. World Health Organization. Available at: https://www.who.int/emergencies/diseases/ novel-coronavirus-2019.

4. Flexman AM, Abcejo A, Avitisian R, de Sloovere V, Highton D, Juul N, Li S, et al.
Neuroanesthesia practice during the Covid-19 pandemic: Recommendation from Society for Neuroscience in Anesthesiology \& Critical Care (SNACC). Journal of Neurosurgical Anesthesiology 2020

5. Rodriguez-Morales AJ, Cardona-Ospina JA, Gutierrez-Ocampo E, Villamizar-Pena R, Holguin-Rivera Y, Escalera-Antezana JP, et al. Clinical, laboratory and imaging features of COVID-19: A systematic review and meta-analysis. Travel Med Infect Dis 2020: Mar 13:101623.

6. Zhao W, Zhong Z, Xie X, Yu Q, Liu J. Relation between chest $\mathrm{CT}$ findings and clinical conditions of coronavirus disease (COVID-19) pneumonia: a multicenter study. AJR Am J Roentgenol 2020 Mar 3

7. Guan WJ, Liang WH, Zhao Y, Liang HR, Chen ZS, Li YM, et al. Comorbidity and its impact on 1590 patients with Covid-19 in China: A Nationwide Analysis. Eur Respir J 2020 Mar 26.

8. Zhou F, Yu T, Du R, Fan G, Liu Y, Liu Z, et al. Clinical course and risk factors for mortality of adult in patients with COVID-19 in Wuhan, China: a retrospective cohort study. Lancet 2020;395: 1054-62.

9. Window for detection of SARS-COV-2 infection. ctkbiotech.com

10. 10. Mao L, Wang M, Chen S, He Q, Chang J, Hong C, et al. Neurological manifestations of hospitalized patients with COVID-19 in Wuhan, China: a retrospective case series study. medRxiv 2020

11. Filatov A, Sharma P, Hindi F, Esoinosa PS. Neurological complications of coronavirus disease (COVID-19): encephalopathy. Cureus 2020;12: e7352.

12. Li Y, Wang M, Zhou Y, Chang J, Xian $\mathrm{Y}$, Wang $\mathrm{D}$, et al. Acute cerebrovascular disease following COVID-19: a single 
center, retrospective, observational study (3/3/2020). Available at SSRN: https://ssrn. com/abstract $=35500252020$.

13. Zoia C, Bongetta D, Veiceschi P, Cenzato M, Meco FD, Locatelli D, et al. Neurosurgery during the COVID-19 pandemic: update from Lombardy, northern Italy. Acta Neurochir (Wien) 2020 Mar 28.

14. Baig MA. Neurological manifestation in COVID-19 cause by SARS-CoV. CNS Neurosci Ther. 2020;00:1-3.

15. Kolikonda MK, Jandrasupali KK, Lippman S. Assosiation of coronavirus disease 2019 and stroke: a rising concern. Neuroepidemiology 2020;54:370-74

16. Society of British Neurological Surgeon. Transmission of covid-19 during neurosurgical procedures. 20 April 2020

17. The use of personal protective equipment by anesthesia professionals during the COVID-19 pandemic. American Society of Anesthesiologists 2020. Available at: https:// www.asahq.org/about-asa/newsroom/news- releases/2020/03/update-the-use-ofpersonalprotective-equipment-by-anesthesiaprofessionals-during-the-covid-19-pandemic.

18. Patel ZM, Fernadex-Miranda J, Hwang PH, Nayak JV, Dodd R, Sajjadi H, et al. Letter: precautions for endoscopic transnasal skull base surgery during the COVID-19 pandemic. Neurosurgery 2020. Available at: https://www.entnet.org/sites/default/files/ uploads/covid 19_endosb_lettertoeditor neurosurgery_update3.23.20.pdf.

19. Chen X, Liu Y, Gong Y, Guo X, Zuo M, $\mathrm{Li} \mathrm{J}$, et al. Perioperative management of patients infected with the novel coronavirus: recommendation from the Joint Task Force of the Chinese Society of Anesthesiology and the Chinese Association of Anesthesiologists. Anesthesiology 2020 Mar 26.

20. Cook TM, El-Boghdadly K, McGuire B. McNarry AF, Patel A, Higgs A. Consensus guideline for managing the airway in patients with COVID-19. Anesthesia 2020;75:789-99 